THE FIRST INTERNATIONAL CONFERENCE ON SURVIVORS OF RAPE

- A MULTI DISCIPLINARY APPROACH

NOVember 14 - 152008 AARHUS, DENMARK

\title{
Abstract BoOK
}


We would like to thank the following institutions and companies for supporting the First International Conference on Survivors of Rape:

Det kriminalpræventive råd

Familien Hede Nielsens Fond

Sanofi Pasteur MSD ApS

The First International Conference on Survivors of Rape

- a multi disciplinary approach

Abstract Book

The Sexual Assault Centre

Aarhus University Hospital

Center for Voldtægtsofre, Århus Universitetshospital, Århus Sygehus 2008 www.voldtaegt.dk

Print: Århus Sygehus

ISBN: 87-988678-5-7 


\section{The First INTERNATIONAL CONFERENCE ON SURVIVORS OF RAPE - A MULTI DISCIPLINARY APPROACH}

The main aim of the conference is to explore some of the challenges in the treatment of survivors of sexual assaults. Many assault survivors still suffer mentally and physically years after the assault. By presenting research on the mental and physical consequences of rape, on different models of treatment of survivors of rape, as well as on the work of the police and the legal system, we hope that the conference will lead to some answers on how to make sure that rape survivors are offered the best forms of care and support - medically, psychologically as well as judicially.

The First International Conference on Survivors of Rape is organized by the Sexual Assault Centre at Aarhus University Hospital in corporation with the Department of Psychology, Aarhus University, the Institute of Forensic Science, Aarhus University, the Department of Gynaecology at Aarhus University Hospital and the Police District of Eastern Jutland.

It is our great pleasure as programme committee to welcome you to the First International Conference on Survivors of Rape,

Ask Elklit, Dept. of Psychology, University of Aarhus

Anja Hareskov Jensen Sexual Assault Centre, Aarhus Univ. Hospital, Annie Vesterby, Inst. of Forensic Medicine, Univ. of Aarhus

Bodil Clemensen, Emergency Dept., Aarhus Univ. Hospital

Ole Brink, Dept. of Orthopaedics, Aarhus Univ. Hospital

Bjarne R. Kristensen, Dept. of Gynaekology, Aarhus Univ. Hospital

Sara Parding, Sexual Assault Centre, Aarhus Univ. Hospital 


\section{Programme}

\section{THURSDAY $13^{\text {TH }}$ OF NOVEMBER}

Extra Pre-conference workshop 13-17:30

\section{Prevention of Sexual Violence: What Works?}

Mary P. Koss, PhD, Regents' Professor of Public Health, Mel and Enid Zuckerman College of Public Health, University of Arizona and Rikke Holm Bramsen, Ph.D.fellow, Department of Psychology, University of Aarhus

The workshop will:

1. Review the interpersonal violence prevention activities recommended by the World Health Organization

2. Analyze the effectiveness of prevention education, self-defence, bystander programs, and media campaigns with adolescents and young adults based on North American evaluations.

3. View media that are aimed at rape prevention

4. Facilitate discussion of features that will shape the Danish national plan for sexual violence prevention.

5. Identify the next steps

\section{FRIDAY $14^{\text {TH }}$ OF NOVEMBER}

\section{9:00-10:00 Registration}

Auditorium A, Aarhus University Hospital, Skejby

\section{0:00-10:10 Welcome}

Anne Thomassen, Medical Director, Aarhus University Hospital

\section{0:10-10:50 Acute Forensic-medical Examination}

A state of the art Nordic and international overview Kari Ormstad, MD, PhD, Professor, Institute of Forensic Medicine, Oslo University

\section{0:50-11:15 Forensic Nursing on Both Sides of the Atlantic}

Nursing at the Rape Crisis Center in Aarhus and Boston Vicky Bredkjær Larsen, Nurse, Sexual Assault Centre, Emergency Department, Aarhus University Hospital 
11:35-12:15 Health Services for Adult Women after Sexual Assault Berit Schei, MD, Professor, Department of Community Medicine, Norwegian University of Science and Technology

\section{2:15-13:15 Lunch}

\section{3:15-14:05 Short Presentations}

Stockholm Emergency Clinic for Raped Women in Stockholm South Hospital Lotti Helström, MD PhD, Stockholm Emergency Clinic for Raped Women, Sweden

Sexual assault care- and treatment programs require new and outreaching methods

Birgit Fladby, Sexual Assault Care Centre, Oslo Emergency Ward, Norway

Chlamydia - Prevalence and Treatment among Sexual Assault Victims

Peter Hjorth Jørgensen, Centre for Sexual Assault Victims, Copenhagen University Hospital, Denmark

Surviving childhood rape and attempted rape Mette Lise Vinum, Team for Sexually Abused Children, Copenhagen University Hospital, Denmark

14:05-14:45 Ideological Settings and the Notion of the (Rape) Victim Annika Snare, D. Crim., Associate Professor, Faculty of Law, University of Copenhagen

\section{4:45-15:05 Break}

15:05-15:35 The collection, analysis and interpretation of DNA-evidence Leif Schiønemann, Detective Inspector, The Danish National Police \& Hans Jakob Larsen, Ph.D. Forensic Geneticist, University of Copenhagen.

\section{5:35-16:00 Rape Investigation across Borders} Preben Juel Hansen, Detective Commander, Denmark. Former Head of the Danish Liaison Bureau at Europol, Den Haag, Nederland 


\section{SATURDAY $15^{\text {TH }}$ OF NOVEMBER}

9:00-9:25 The Criminal Proceedings in Rape Cases in Denmark Lasse Lund Madsen, Associate Professor, Aarhus University School of Law

9:25-10:15 Using Restorative Approaches to Address Sexual Assault Mary P. Koss, PhD, Regents' Professor of Public Health, Mel and Enid Zuckerman College of Public Health, University of Arizona

10:15-10:45 Break

10:45-11:10 How Police Interviewing Works

Interviewing Techniques and Police Questioning of Survivors of Rape

Gitte Christensen, Detective Inspector, The Police District of Eastern Jutland

\section{1:10-11:50 Short Presentations}

Marianne Bachmeier: The Irrational Shadow of the Victim Mark Thomas, BA (Hons) LLB (Hons), Lecturer, Faculty of Law, Queensland University of Technology, Brisbane, Australia

Prosecuting rape before international criminal tribunals Niamh Hayes, Irish Centre for Human Rights, National University of Ireland

\section{1:50-12:50 Lunch}

\section{2:50-13:20 Trying to Fit in, yet Standing Out}

Psychological Consequences of Rape and Attempted Rape, Psychotherapeutic Treatment and the Process of Recovery Annalise Rust, MSc in Psychology, The Centre for Victims of Sexual Assault, Copenhagen University Hospital

13:20-13:50 Psychotic Symptoms in Rape Survivors: Signs of trauma, not schizophrenia

Andrew Moskowitz, Ph.D. Clinical Department of Mental Health, University of Aberdeen

\section{3:50-14:20 Short Presentations}

Prisoner Rape Using Narrative Therapy to Address Sexual

Assault in Men's Prisons

Andrew Robert Duggan, Senior Lecturer, School of Health and Human Sciences, University of Huddersfield, England

Cognitive behaviour group treatment for adolescent girls after a single rape

Iva Bicanic, University Medical Center, Psychotrauma Center for Children and Youth, Utrecht, The Netherlands 
14:20-14:45 Break

14:45-15:15 Sexual Torture of Women as a Weapon of War: The case of Bosnia-Herzegovina

Libby Arcel, Associate Prof., MSc., Department of Psychology, University of Copenhagen

15:15-15:35 A Register Study of Post-Rape Health Care Use Ask Elklit, Professor, MSc, Department of Psychology, University of Aarhus

15:35-16:00 Legal and Health Consequences of Sexual Violence in Aarhus

Ole Ingemann-Hansen, MD, PhD, Institute of Forensic Medicine, University of Aarhus 


\section{The First International Conference on Survivors of Rape \\ - A multi disciplinary approach}

\section{Submitted abstracts}

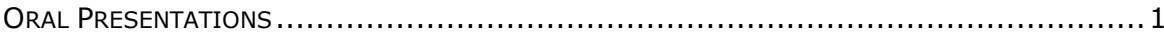

Acute Forensic-medical Examination (FME): ................................... 2

Forensic Nursing on Both Sides of the Atlantic: .................................... 3

Health Services for Adult Women after Sexual Assault.............................. 5

Stockholm Emergency Clinic for Raped Women in Stockholm South Hospital...7

Sexual assault care- and treatment programs require new and outreaching

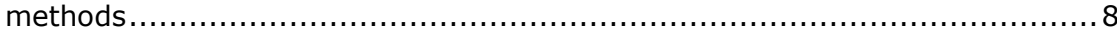

Chlamydia: Prevalence and Treatment among Sexual Assault Victims ......... 10

Surviving Childhood Rape and Attempted Rape .................................... 11

Ideological settings and the notion of the (rape) victim ......................... 13

The Collection, Analysis and Interpretation of DNA-evidence .................... 14

Rape Investigation across Borders ................................................ 15

Criminal Proceedings in Rape Cases in Denmark ................................. 16

Using Restorative Approaches to Address Sexual Assault ........................ 18

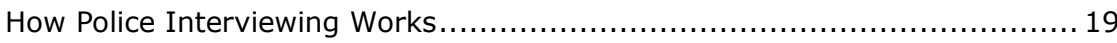

Marianne Bachmeier: The Irrational Shadow of the Victim ...................... 20

Prosecuting Rape before International Criminal Tribunals........................ 22

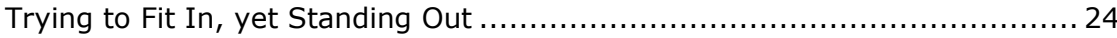

Psychotic Symptoms in Rape Survivors: Signs of trauma, not schizophrenia . 26 Prisoner Rape: Using Narrative Therapy to Address Sexual Assault in Men's Prisons ............................................................................ 28

Cognitive Behaviour Group Treatment for Adolescent Girls after a Single Rape

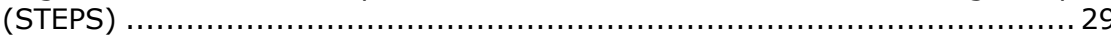

Sexual Torture of Women as a Weapon of War: The Case of Bosnia-

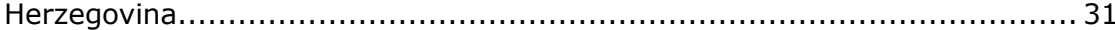

A Register Study of Post-Rape Health Care Use ................................. 32

Legal and Health Consequences of Sexual Violence in Aarhus..................... 33

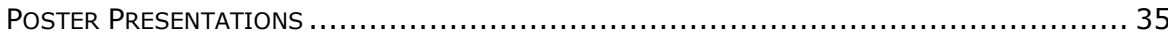

Was it Rape? A Study of Human Rights and Rape Cases in Denmark ............ 36

Case Closed - Rape and Human Rights in the Nordic countries.................. 38

Legal Issues on Rehabilitation of Rape Survivors .................................. 39

The Role of the Judicialry and Community Based in the Fight Against Rape... 40 Support Strategies for Women Affected by War-related Sexualised Violence . 41 Expanding Punishment: The Need for a Coordinated Legal and Public Health Response for Victims of Systematic Rape in Post-Conflict Settings .............. 42

Prosecuting Rapists in Wars: Bosnia and Rwanda Cases ......................... 43 
Rape in Genocide................................................................. 44

The Subdued Silence: the Case of Former Jugun Ianfu in Indonesia............ 45

ASD and PTSD in Rape Victims ................................................... 46

Predictors of Aacute Stress Symptoms in Rape Victims........................... 47

The Adolescent Resilience Programme: Ending Inter-generational Sexual

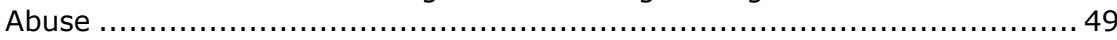

Identifying Risk Behavior and Attitudes on Sexual Coercion among Adolescents

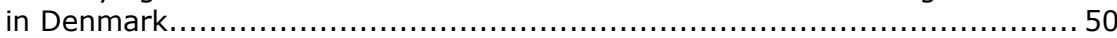

Trends of Rape among Secondary Schools, South West, Nigeria ................ 51

Barriers for Help Seeking after Sexual Victimization in a Danish Context ...... 52

Rural Communities: No Rapes or No Help?....................................... 53

Rape Survivors Assaulted more than 6 Months ago.............................. 54

Contextual Psychosocial Approach in Rehabilitation Program of Vive Žene

Centre............................................................................. 56

Dressed for Rape: Anonymous Voluntary Counselling for Female Victims by the Danish Joan-Sisters ................................................................. 57

The Psychological Consequences of Rape for Friends and Relatives ............. 58

Counselling Relatives of Rape Victims ............................................ 59

The Psychological Background of False Rape Accusations.........................60 60

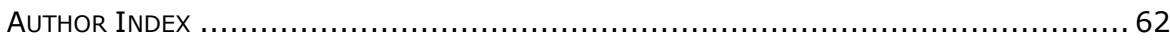




\section{Oral Presentations}




\section{Acute Forensic-medical Examination (FME):}

\section{A state of the art Nordic and international overwiew}

Kari Ormstad, MD, PhD, Professor. Institute of Forensic medicine, University of Oslo, Norway

Facilities established to assist victims of sexual assault should ideally cater to clinical diagnostic/therapeutic, psychosocial as well as forensic needs. The structure and organisation of these specialised outpatient clinics depend on whether they are open to all help-seeking subjects or primarily perform examinations requested by the police after a formal complaint has been filed. Nevertheless, all aspects of the service should preferably be taken care of during one visit. To facilitate victims' attendance as early as possible, and to secure reliable evidence in case of police investigation and court proceedings, the service should be made publicly known, easily acessible $24 / 7$ and run by competent staff. Appropriate routines should be implemented to minimise examination-related discomfort/trauma and to secure reliable samples for analysis and documentation of physical findings. Furthermore, resources should be spent where most useful.

The following issues should be considered concerning FME:

- Limitation of accepted interval from assault to visit

- Limitation of accepted interval from assault to trace evidence collection

- Impact of victim's decision regarding police involvement

- Routines for physical examination (i.a. colposcopy)

- Routines for documentation of examination and sampling (rape kit, standardised patient record, photo, video)

- $\quad$ Routines for sampling, labelling and storage of trace evidence (rape kit, chain of custody, storage facilities)

- Victims' right to be informed about results of examination and analyses also when refusing police involvement

Decisions on policy and procedures should be scientifically based and when feasible, properly adjusted according to new knowledge.

Routines vary among cities and countries, partly because of different organisational and fiscal factors, partly because of more or less well-founded tradition. Our aim should be to reach an international consensus based on modern insights and data, to supply optimal medicolegal service for sexual assault victims irrespective of gender and nationality and to visualise and promote the importance of appropriate funding of sexual assault care and continuous education to ensure high-level professionality in involved staff. The human rights, legal rights and sociomedical welfare of victims are primarily at stake, but any unjustly suspected perpetrator may also benefit from professionally conducted forensic medical casework. 


\section{Forensic Nursing on Both Sides of the Atlantic:}

Nursing at the Rape Crisis Center in Aarhus and Boston

Vicky Bredkjær Larsen, Nurse, Sexual Assault Centre, Emergency Room, Aarhus

University Hospital

Keywords: Sexual assault survivor, SANE, Rape Crisis Center

Introduction: The Sexual Assault Centre in Aarhus is located at the Emergency Room of Aarhus University Hospital. The Centre offers: nurses who are specially trained to take care of sexual assault survivors and their family, medical treatment, forensic examination, counselling by psychologists and follow up procedure.

In Boston 7 hospitals are part of the Sexual Assault Nurse Examiner (SANE) Program. SANE's are specially trained and certified, and they work together with the Boston Area Rape Crisis Centre and Centre for Violence Prevention and Recovery.

Nursing visit: To learn about SANE work model, I was at a nursing visit in Boston in September 2008, where the SANE's explained their work and the service they offer sexual assault survivors.

The purpose of the visit was to experience which kind of offers a SANE has for a sexual assault survivor and to compare the work model of a SANE and the work model at the Centre for Sexual Assault in Aarhus. To develop the nursing at the Centre in Aarhus it is important to get ideas and experiences from others who work with sexual assault survivors.

Differences: There are many differences between the work model for a Boston SANE and a nurse at the Sexual Assault Centre in Aarhus. Particular interesting is the difference in who is collecting the evidence. A SANE performs forensic medical-legal examinations in Boston, in Aarhus the examinations is preformed by a physician, either from the Institute of Forensic Medicine or a physician or from a corps of volunteer physicians who are trained in forensic examinations. In Boston evidence can be collected within 5 days of the assault, in Aarhus within 3 days.

An other big difference is that a SANE always provides preventative treatment for HIV and hepatitis, in Aarhus the nurses do not.

In the Boston area a SANE is on call. In Aarhus a nurse is working at the Emergency room until a sexual assault survivor arrives. When the survivor arrives 
the nurse is available immediately to assist the survivor for the duration of her/his stay at the centre.

The Boston Area Rape Crisis Center have volunteers who supports the sexual assault survivor during the examination and after. Such volunteers are not available in Aarhus. Instead a psychologist at the centre counsels the survivor after the assault. 


\section{Health Services for Adult Women after Sexual Assault}

Berit Schei. Professor/Consultant, Institute of Public Health /Sexual Assault Care Center, Department of obstetric and gynaecology, St.Olavs hospital, Trondheim University Hospital, N-7489 Trodnheim, Norway.

Violence against women is reported globally. Detrimental effects on health, both immediate and long term can be devastating. The needs of a victim differ whether she seeks assistance immediately after an assault or consult for symptoms and disorders without disclosing an abuse history $\left({ }^{1}\right)$. My presentation will focus on the quality of health care services immediately after an incidence of rape, attempted rape and other types of sexual assaults. The aim of such a service is to assist the victim in restoring health in a broad sense by offering acute crisis interventions and medical treatment. Secondly, in case of police reporting either at the time of consultation and at a later stage, the service should include optimal forensic trace evidence collection and systematic documentation of injuries. In order to pursue these aims, the health care services should be open to all victims regardless of police reporting $\left({ }^{2}{ }^{3}\right)$. The qualification of health care professionals should be based on adolescence paediatrics and gynaecology as well as forensic medicine $\left({ }^{4}\right)$. The rights of the victims include medical services free of charge, as well as psychosocial support and legal advice in case of prosecution of the offender. The consultation and medical examination including the gynaecological assessment should take into account the victims need to regain control, initiate healing and restore health. Victims represent a vulnerable group of patients and run the risk of re traumatisation by the services $\left({ }^{5}\right)$. To experience

${ }^{1}$ Hilden $M$, Schei $B$, Swahnberg $\mathrm{K}$ et al. A history of sexual abuse and health: a Nordic multicentre study. Br J Obstet Gynaecol 2004; 111 (10): 1121-7.

${ }^{2}$ Schei B, Sidenius K, Lundvall L, Ottesten LG. Adult victims of sexual assault: acute medical response and police reporting among women consulting a center for victims of sexual assault. Acta Obstet Gynecol Scand 2003; 82: 750-5.

${ }^{3}$ Haugen $\mathrm{K}$, Slungård A, Schei B. Sexual assault of women - injury pattern and victim-perpetrator relationship. Tidsskr Nor Lægeforen 2005; 125.

${ }^{4}$ Hilden M, Schei B, Sidenius K.

Genitoanal injury in adult female victims of sexual assault.

Forensic Sci Int. 2005 Nov 25;154(2-3):200-5.

${ }^{5}$ Swahnberg K, Schei B, Hilden M, Halmesmäki E, Sidenius K, Steingrimsdottir T, Wijma B.Patients' experiences of abuse in health care: a Nordic study on prevalence and associated factors in gynecological patients. Acta Obstet Gynecol Scand. 2007;86(3):349-56. 
health care as abusive is unrelated to the health care providers' intention. It is therefore crucial that health service is built on evidence based procedures and highly qualified and technical skilled staff. Also, results from all tests regardless of indications, clinically as well as forensic trace analysis as e.g. identification of drugs in blood samples and identification of sperms should be free accessed by the victims. 


\section{Stockholm Emergency Clinic for Raped Women in Stockholm South Hospital}

Lotti Helström, MD PhD. Anna Möller, MD, Kristina Pettersson, Med Stud, Klara Ravald Med Stud.

Introduction: The Emergency Clinic for Raped Women started in October 2005, to admit women who have been subjected to acute sexual assault. The clinic is open 24 hours a day; the staff includes gynaecologists special trained for gynaecologic forensic investigation, midwife nurses, psychologist and social workers trained for trauma treatment. The women are offered forensic investigation, tracing and post exposition prophylaxis for sexual transmitted diseases, medical follow up, as well as trauma counselling. The clinic has close collaboration with the police, social authorities, youth clinics, women shelters, psychiatric clinics and addiction centres. The clinic also provides internship for doctors from other hospitals.

Data for the first three years will be presented.

Method: Data from patient files were analyzed.

Results: Roughly 600 women are met every year, and 3000 follow consultations to gynaecologist, counsellor or nurses are performed. The most common perpetrator was a person acquainted to women (31\%), a person completely unknown to the woman $(17 \%)$, a partner or ex-partner $(13 \%)$, while every eight $(12 \%)$ case more than perpetrator was involved.

In $12 \%$ of the cases the woman had amnesia for the rape, due to drug and/or alcohol and in $58 \%$ of the cases the women had been drinking at the time before the rape.

The majority of the women (67\%) showed signs of violence when examined, the most common sign being bruises or lacerations on arms or legs (87\%). In $40 \%$ of the cases genital signs were seen; mainly slight damage to the mucosa. Signs were more common when the perpetrator was related to the woman.

Half of the women (55\%) of the women report the assault to police, and in $65 \%$ of those cases forensic reports were required by legal authorities. Women were less prone to reporting to the police if the perpetrator was a close person.

Conclusion: During the first three years of the clinic the number of women attending has increased by approx. $10 \%$. The increase might be a result of improved knowledge about the clinic, a real increase in number of sexual assault crimes or an effect of women not accepting to remain silent about crimes committed against them. 


\section{Sexual assault care- and treatment programs require new and outreaching methods}

Birgit Fladby, senior advisor, Psychosocial unit, Sexual assault care center, Oslo emergency ward, Norway

Key words: Sexual Assault; Crisis Intervention/methods; Emergency Services

Introduction: The Oslo Sexual assault center (SAC) established in 1986, offers forensic examination, medical and psychosocial immediate care and follow-up. Experience evokes concern regarding the target group: 1. Lower than expected attendance among subjects of Non-Norwegian ethnicity, males, visually handicapped and teenagers. 2. Follow-up compliance is low. 3. Only $5-10 \%$ of local SA victims seek SAC-based assistance. To explore these trends, SAC's psychosocial unit in cooperation with ATV (Alternative to Violence ${ }^{6}$ ), in 2004/2005 performed a needs assessment focusing victims exposed to sexual assault.

Purpose: To improve the psychosocial support programs for SA victims. The Needs assessment investigated perceived obstacles to help-seeking for SA victims, possible ways for SAC to facilitate immediate attendance and increase follow-up compliance.

Method: Qualitative methods; depth interviews and focus group interviews, using interview guide. Informants: SA victims, non-exposed subjects and professional staff members. SAC's patients were not recruited as informants. Contact with informants was established through public advertisements. Nobody of NonNorwegian extraction responded.

\section{Results from target group interviews:}

- Visually and auditively handicapped informants did not know about aid programs.

- Males presumed the program addressed women exclusively.

- Ethnical Norwegian women were aware of SAC but often considered themselves not "qualified" for help as their perceptions of "qualified" included sober and physically injured victims, unknown perpetrator, and assault by blitz attack.

The informants were also asked whether outreaching assistance would feel insulting or invading. The answers were unambiguous:

- an outreaching program represents care and concern

- victims often need to be collected at home, as emergency aid

- a phone call the day after SAC visit would be appreciated

${ }^{6}$ Alternative to Violence is the eldest European specialised treatment program for victims and assailants in family-related incidents. 
- victims need to be contacted in case of drop-out

- victims need a psychosocial follow-up program

- victims appreciate a follow-up call one year post-assault.

Conclusions: Trauma reactions following SA include guilt, shame, self-reproach, lack of confidence, withdrawal, avoidance, and confusion. Such reactions represent substantial obstacles to help-seeking for necessary assistance, reinforced by victims' stereotypic perceptions of rape and sexual assault. Support programs must overcome these obstacles. SACs should implement active outreach in order to facilitate immediate attending and post visit follow-up .Particularly marginal victim groups need specific information and outreaching support. 


\section{Chlamydia: Prevalence and Treatment among Sexual Assault Victims}

Peter Hjorth Jørgensen, Malene Hilden, Anne-Marie Worm, Centre for Sexual Assault Victims - Rigshospitalet

Key words: Chlamydia, Sexual assault, Prophylactic Antibiotic Treatment

Aims: With onset in general facts concerning chlamydia in Denmark, the purpose was to dertermine, by data from Centre for Sexual Assault Victims -

Rigshospitalet (CFV-R), the prevalence of chlamydia among female sexual assault victims and also to evaluate the prophylactic antibiotic treatment of chlamydia at CFV-R over a five year period from 2001 to 2005.

Method: The study is based on data from 1.164 women registered in the database of CFV-R; regarding risk of infection during the assault, together with; testing, prevalence and treatment of chlamydia of these women.

Results: $74 \%(861 / 1164)$ of the women had been in risk of infection, and of these $72 \%$ (620/861) were tested and 10,3\% (64/620) had chlamydia. Among the other $26 \%$ (303/1164), without risk of infection, $50 \%(151 / 303)$ were tested and $10,6 \%(16 / 51)$ had chlamydia. In the group of women with risk of infection $80 \%(681 / 861)$ were prophylactic treated, opposite $44 \%(132 / 303)$ among the women without risk of infection. In total $86 \%(69 / 80)$ of all chlamydia infections were treated. 79 cases of genital chlamydia were found, $34 \%(27 / 79)$ solely in the cervix and $25 \%(20 / 79)$ solely in the urethra. Only women with oral or anal penetration were tested for chlamydia in the fauces or rectum. Among these, $5 \%$ $(7 / 150)$ were tested in the fauces without any positive findings. $28 \%(41 / 144)$ were tested in the rectum, and 6 positive results were found, one case solely in the rectum.

Conclusion: In this study we found that the prevalence of chlamydia among women attending CFV-R, in the period of 2001 to 2005, were high compared to former Danish studies. We also found that the prevalence of chlamydia were independent of having been at risk of infection during the assault though the study showed a tendency of more women with risk of infection being tested and treated. CFV-R should continue to test and prophylactically treat for chlamydia among all attending sexual assault victims, not regarding risk of infection. 


\section{Surviving Childhood Rape and Attempted Rape}

Mette Lise Vinum, Helene Almind Jansen, Iben Warring Madsen, University

Hospital Rigshospitalet, Team for Sexually Abused Children, Copenhagen,

Denmark

Introduction: Since 2001, 757 children between 0-15 years exposed to sexual abuse or rape, have received psychological and physical treatment at Rigshospitalet, Team for Sexually Abused Children. Among these children 150 were between 11-15 years and exposed to rape or attempted raped.

Purpose: The aim of the study is to examine youth - youth rape or attempted rape, exploring the psychological and psychosocial consequences of this type of assault, the characteristics of the psychological treatment, the significance of the assault being the young persons sexual debut and the resons for reporting the rape or attempted rape to the police. Further more we wish to investigate some of the social patterns underlying youth - youth rape or attempted rape.

Methods: Using clinical records, sociodemographic registration and medical records, data where obtained and analyzed for the 150 children aged $11-15$ years exposed to rape or attempted rape.

\section{Results:}

Report of the rape or attempt: 118 of the children (79\%) reported the rape or the attempted rape to the police. 17 children (11\%) did not report the rape or attempt.

Sex: 145 (97\%) of the children were girls. 5 (3\%) of the children were boys.

Psychological treatment: 55 (37\%) children received no psychological treatment.

$57(39 \%)$ children received between $1-5$ consultations with a psychologist. 20 $(13,5 \%)$ of the children had between $6-12$ consultations with a psychologist. $16(10,5 \%)$ children received more than 13 consultations with a psychologist.

Offenders age \& Nationality: 53 (35\%) of the children were raped or attempted raped by an adult. $62(41 \%)$ of the children were raped or attempted raped by a young person between the age of $15-18$ years. 20 (13\%) of the children were raped or attempted raped by a young person between $12-14$ years old.

In $71(47 \%)$ cases the offenders' nationality was Danish. $32(21 \%)$ of the offenders came from the Middle East or Africa.

Among the Danish offenders 10 (14\%) were between $12-14$ years old and $34(47 \%)$ were between $15-18$ years old, while 29 (40\%) were adults.

Among the Middle East /African group of offenders 4 (13\%) were between 1214 years old, 17 (53\%) were between $15-18$ years old, and 11 (34\%) were adults. 
Discussion: The presentation will look behind these results, and analyze the outcome, with a special focus on understanding youth / youth rape and the psychological and psychosocial consequences of this. 


\section{Ideological settings and the notion of the (rape) victim}

Annika Snare, D.Crim, Associate Professor, Faculty of Law, University of Copenhagen

The point of departure is two Swedish governmental reports on sexual offences presented five years apart, one in 1976 and the other in 1981. The fate of the first report tells the story about how the conception of rape and rape victims was transformed within this very short period of time while the committee - seemingly unaware of an ideological shift - was at work. The extent to which this change of lenses resulted in actual reforms is not the issue here, but it is well known that ideals are frequently not in accord with practices.

Instead the second topic addresses the vanguard role that victims of sexual assault - and battered women - played in shaping an emergent victim orientation in criminal policy. Internationally/regionally as well as in national legislations and through local initiatives, formerly invisible and ignored victims of crime were acknowledged. Although other background factors contributed, it is generally agreed that the exposure of these vulnerable victims by the women's movement and research functioned as starting signal for broader victim concerns and political attention.

The third and final subtheme briefly relates how the crime of rape is not a onedimensional phenomenon, independent of time and place. Even in a comparatively homogenous context like the Nordic countries, there are differences in the application of the rape notion in legislation and subsequently in criminal statistics 


\section{The Collection, Analysis and Interpretation of DNA-evidence}

Leif Schiønemann ${ }^{1}$ \& Hans Jakob Larsen ${ }^{2} .{ }^{1}$ Crime Scene Unit, Nat Cent. Of Forensic Service, The Danish National Police; University of Copenhagen; ${ }^{2}$ Section of Forensic Genetics, Department of Forensic Medicine, Faculty of Health Science, University of Copenhagen

Keywords: Collection of evidence, DNA-profile, likelihood ratio

Collection and analyses of biological trace material and stains are often essential when documenting physical contact between two or more persons in crime cases such as sexual assault. In Denmark, trace material is routinely collected by the sexual assault centres, the institutes of forensic medicine, or the police. The evidence is submitted to Section of Forensic Genetics, at the University of Copenhagen, where the analyses are performed.

Usually, evidence is analysed for the presence of biological material such as blood, semen, etc. When relevant, the biological trace is typed using DNA-profile analysis. By comparing the DNA-profile of the biological trace to those of the implicated persons, it can be decided whether or not the material may originate from a specific individual. If possible, the statistical weight of the evidence is presented as a likelihood ratio.

Our talk will describe the cooperative effort of the police and the geneticist when investigating sexual assault cases. We will discuss the strategies, possibilities, considerations, and choices made in this respect. Finally, we will present how the statistical weight of the DNA-evidence may be interpreted and put into context with the rest of the case information. 


\section{Rape Investigation across Borders}

Preben Juel Hansen, Detective Commander, Denmark. Former Head of the Danish Liaison Bureau at Europol, Den Hauge, The Netherlands.

The EU resolution on mobility of labour, the Schengen convention on abolition of control at frontiers related to the globalisation require increased demands on a professionally and efficiently performed investigation of crimes committed in Denmark by persons, who have no fixed relations to Denmark. If a foreigner is arrested in the country where the crime took place, the offender is accorded equal treatment as the own citizens of the nation.

It is a different matter, if the offender has left the country and investigation and prosecution must take place in the offender's country. It is a fact that every individual country will protect its own citizens against the judicial authorities of other nations. Of course it is not the intention that a person cannot be prosecuted for crimes committed abroad, if the offender has returned to his/her own country before the crime has been solved and prosecution can be initiated against the person in question.

Thus, like other countries Denmark has ratified various conventions that permit prosecution across the borders. Most important are the convention on mutual assistance in criminal matters, the Schengen convention, the Europol convention, and the EU Council Decision on the foundation of Eurojust. Also the INTERPOL Cooperation plays an important part in cross border co-operation between law enforcements agencies.

Especially the use of the convention on mutual assistance in criminal matters is slow and often it demands considerable resources. Therefore, untiring efforts are performed to soften up the co-operation between law enforcement agencies across the borders. Years ago the optimization of the cross border police cooperation was slow, and the steps forward have been small, however, the political efforts of later years and a common wish for reforms have shown progress that previous would have taken decades to accomplish.

The development of the international police co-operation is far from ended. At the moment the European countries are working on the implementation of the technical measures to ensure the accomplishment of the far-reaching possibilities of co-operation, given pursuant to the Prüm treaty. This treaty gives quite new possibilities to investigations of rape cases and other crimes related to persons.

Finally, we can establish that in the future border crossing investigations will get considerably better conditions than they have today. The individual legal means and their significance will be mentioned in connection with the presentation. 


\section{Criminal Proceedings in Rape Cases in Denmark}

Lasse Lund Madsen PhD, Assistant Professor, School of Law, The Faculty of Social Sciences, Aarhus University

According to $\S 216(1)$, first sentence, of the Criminal Code, 'Any person who enforces sexual intercourse by violence or under threat of violence' is guilty of rape and liable to imprisonment for up to eight years.

Rape involves the use of compulsion in the form of violence or the threat of violence. Depending on the circumstances, the element of violence or the threat need not be particularly manifest. In more recent cases there have been convictions by reference to an implicit threat of violence in the context of the situation. However, these cases present problems of proof. The prosecution must prove the guilt of the accused beyond all reasonable doubt and must assess the case objectively, including ensuring that accusations are not made against innocent persons. The accused has a right to be assigned a defence lawyer, and the injured party may also be given legal aid.

A conviction for rape requires the existence of intention. The accused must realise there is compulsion by violence or the threat of violence and thus they must realise that (in practice) the woman does not want or does not agree to the sexual intercourse.

In Danish law it is not possible to punish someone for negligent rape. However, there are a number of other provisions in the Criminal Code which criminalise the obtaining of sexual intercourse other than by violence or the threat of violence. For example this can be by the use of a milder form of compulsion, various forms of exploitation etc.

Internationally there seems to be a trend away from the traditional emphasis of the element of compulsion and violence in the concept of rape, and towards an increased focus on a woman's right of self-determination. In this approach there is a greater emphasis on whether the woman has consented to sexual intercourse or not. If not, then there will be considered to be rape. This is an extension of the concept of rape as understood in Danish law. This must be assumed to lead to a number of difficulties about definitions and to some grey areas in the criminal law.

In relation to sentencing, in Danish practice rape is divided into three categories: violent rape, date rape and partner rape. Violent rape is considered the most serious form of rape. For many years the courts' sentencing in rape cases has been criticised for being too lenient. In an amendment to the law in 2002 the maximum sentence was increased by two years. The aim of the legislators was that, in practice, jail terms should be increased by a further year for all three 
categories of rape. In the case of violent rape this should typically mean an increase of the level of prison terms from $1 \frac{1}{2}$ to about $2 \frac{1 / 2}{2}$ years. 


\title{
Using Restorative Approaches to Address Sexual Assault
}

\author{
Mary P. Koss, University of Arizona USA
}

A large international literature promotes restorative justice options as satisfying and empowering to crime victims. A restorative justice conceptualization involves three constituencies: (a) survivor/victims and secondarily victimized family and friends who suffer distress along with their loved one; (b) community members who experience less safety and social connection when they perceive high levels of crime and low deterrence, yet who simultaneously may be contributing to an environment supportive of sexual violence; and (c) offenders as well as their families and friends, who experience guilt and shame that is associated with being accused of a sexual crime or belonging to the interpersonal relationship context from which the offense arose. Restorative options include sharing circles, victimoffender dialogue, victim impact panels, community reparation boards, circles of support, sentencing circles, conferencing with juveniles and adults, and restorative discipline in educational settings. Whereas judicial processes and incarceration primarily aim for deterrence and punishment of the offender, restorative justice can be responsive to survivor needs for validation, empowerment, and repair of harm as well as preventative of future sexual assault. Yet, there has been hesitation extending restorative justice to sexual assault.

Drawing upon published literature and experience running RESTORE, a restorative justice program for sexual crimes, the presentation highlights several types of survivor/victims that could experience enhanced options through restorative approaches including: (a) adult survivor/victims who choose not to initiate a report to law enforcement; (b) those who reported but whose cases were closed against their wishes; (c) survivor/victims whose offenders were never apprehended; (d) adult survivors of child sexual assault who were unable to come forward at the time of the offense; (e) juvenile survivor/victims whose offenders are young family members and friends (providing that the offense was limited to an overly extreme developmentally-driven sexual exploration and not part of a pattern of deviant sexual arousal); and (e) family and friends of survivor/victims, who may suffer equal or more distress than the survivor/victims. There is a credible argument that sexual assault service providers, advocates, and policy makers can take leadership in the development of restorative options both in parallel with and independent from the conventional justice system. Meeting survivor/victims' justice needs and fostering accountability is preventative in itself and bolsters the primary prevention messages that are central elements of rape prevention education programs. Innovation from both inside and outside the justice system would benefit all parties. 


\section{How Police Interviewing Works}

Interviewing Techniques and Police Questioning of Survivors of Rape

Gitte Christensen, Detective Inspector, the Police District of Eastern Jutland.

How do rape victims experience the first contact with the police and how do the police secure a correct and adequate explanation from the victim?

The presentation will explain how the police question victims of rape and the importance of creating an environment that gives the victim a feeling of security, trust and confidentiality for her to share with the interviewer what happened to her during the rape.

In the presentation I will discuss "best practice" in questioning a vulnerable victim and the presentation will go through the phases of a well planed interview. 


\section{Marianne Bachmeier: The Irrational Shadow of the Victim}

Mark Thomas BA (Hons) LLB (Hons), Lecturer, Faculty of Law, Queensland University of Technology, Brisbane, Australia

Introduction/Background: In 1981, Marianne Bachmeier entered a Ludeck courtroom and shot an accused, Klaus Grabowski, seven times. Grabowski was being tried for the rape-murder of Bachmeier's seven year-old daughter, Anna. Convicted of murder, she was sentenced to six years' imprisonment.

Objective/Purpose: This paper explores the phenomenon of the victim impact statement (VIS) in common law jurisdictions, critiquing the underlying assumptions which threaten to reduce them to mere formalities, with no significant role other than the cathartic. Valuable though catharsis may be in the post-trauma environment, the VIS is, as a forensic tool, undermined by the lack of correlation between legal method and the form of the impact statement.

Method: This paper critiques the VIS by reference to the assumptions of forensic process and analysis. Material presented to courts in criminal hearings is mapped within conventional linguistic and epistemological codes, broadcast within what Steiner describes (in a broader, literary, context), as a "field of the prepared echo". 7 The collective, reciprocal linguistic synergy between bench and bar reflects Steiner's observation of the elitist, high culture phenomenon of literacy the text of forensic oratory resonates in a matrix of shared linguistic/analytic conventions deriving from "schooled recognition", dominated by a "pact of common awareness [that] has been negotiated, as it were, before the [bar and bench] meet." 8

Judicial statements which validate the experience of the victim of sexual assault, raising them above their conventional status as a mere resource at the disposal of the prosecution, are rare. Statements which elevate the victim's experience beyond the conventions of punishment or rehabilitation, granting them primacy even in the absence of any conceivable utility in imposing sentence (eg Dupas ${ }^{9}$ ) are rarer still.

More routinely the victim presents a narrative which resonates neither linguistically nor epistemologically within the courtroom. The devaluation of its forensic currency is compounded insofar as it is haunted by the shadow of non-

7 G Steiner, "In a post-culture", in Extraterritorial, Penguin, Harmondsworth, 1972, p164

8 ibid

9 Director of Public Prosections $v$ Dupas, unreported sentencing remarks, Supreme Court of Victoria, Criminal Division, No 1533 of 2006, 27 August 2007 
rationality: despite Bachmeier's attracting considerable public support, her actions create a shadow-self of the victims of sexual assault antithetical to the ordered, detached, rationality of the courtroom - a Foucauldian etranger, deprived of reason by the trauma that is the very subject of proceedings, which contaminates the victim's narrative with the spectre of uncontrolled (and uncontrollable) vengeance.

Conclusion: The victim of the imaginary overbears the victim as the real, colouring her narrative, rendering it inaudible - constructing a forensic trompe I'oeil. The victim may be provided with statutory presence, but the ontology of criminal process denies ththise presence comprehensibility as a forensic artefact. 


\section{Prosecuting Rape before International Criminal Tribunals}

Niamh Hayes , Irish Centre for Human Rights; National University of Ireland, Galway; Galway; Ireland

Keywords: International criminal law; Prosecution of sexual violence; Victims and witnesses

Introduction: This paper is drawn from doctoral research (funded by the Irish Government) assessing the adequacy of prosecutions for rape in international criminal law.

Objective/Purpose: The purpose of the presentation is to highlight some of the legal and practical issues which have impacted on international criminal prosecutions for rape and sexual violence. International criminal tribunals have jurisdiction over war crimes, crimes against humanity and genocide, and over the last fifteen years their jurisprudence has made a valuable contribution in confirming that rape is among the gravest international crimes. Under international criminal law, rape can be considered a war crime, a crime against humanity, a form of torture and even an act of genocide. One of the stated purposes of international criminal law is to provide for an end to impunity, and in many cases an international criminal tribunal investigating a particular conflict can constitute the only forum willing and able to prosecute the most senior leaders who are responsible for ordering or permitting the perpetration of rape and sexual violence on a mass scale.

Despite the achievements of international criminal tribunals in prosecuting rape, there have also been many obstacles and failures along the way. Problems have arisen in relation to the training and staffing of field investigation teams, adequate protection and support services for victims and witnesses before the tribunals, prosecutorial strategy and formulation of indictments, prioritisation of rape and sexual violence in the work of the tribunal and even the formulation of a working definition for the crime of rape in international criminal law. A critical analysis of both the problems and progress to date in prosecutions for rape under international criminal law can provide a more effective foundation for future international prosecutions.

Method: The paper will address the prosecution record of the four international criminal tribunals currently operating - the International Criminal Tribunal for Rwanda, the International Criminal Tribunal for the former Yugoslavia, the Special Court for Sierra Leone and the International Criminal Court - which, in total, deal with seven geographical conflicts - Rwanda, the former Yugoslavia, Sierra Leone, the Democratic Republic of the Congo, Uganda, Darfur and the Central African Republic. 
Results \& Conclusion: This presentation will outline the major achievements of previous prosecutions for rape in international criminal law, explain and analyse the obstacles and difficulties which have been encountered, and conclude by making a series of recommendations to ensure that future international criminal prosecutions of sexual violence are more efficient, sensitive and successful. 


\section{Trying to Fit In, yet Standing Out}

\section{Psychological Consequences of Rape and Attempted Rape,}

Psychotherapeutic Treatment and the Process of Recovery

Annalise Rust

Key words: Rape, ASD, PTSD, psychological interventions.

Introduction: The Centre for Victims of Sexual Assault (CVS), opened March 2000 as an acute ward at Copenhagen University Hospital admitting women and men from 12 years and upwards, who have been exposed to rape or attempted rape within 72 hours before the enquiry. In 2008 more than 300 victims are expected to call at the centre.

Objective/Purpose: A research project has been carried out at CVS with the purpose of generating knowledge and insight into reactions in victims of sexual assault, in order to provide the best possible treatment in the aftermath.

Methods: The background material of the studies included was based on the 994 enquiries at CVS through the years 2001-2004. Assessment of acute and longterm responses to sexual assault was made on an initial group of 50 women (15 44 years of age) referred for psychological treatment at CVS. The women were assessed according to the diagnosis of Acute Stress Disorder (ASD) and Posttraumatic Stress Disorder (PTSD).

Prevalence and severity of trauma symptoms were examined in relation to six variables:

- Age at the time of the assault.

- Intake of alcohol/and or drugs before the assault.

- Experience of own resistance during the assault.

- The type of assault (rape/attempted rape).

- Physical violence or threats of violence from the perpetrator.

- The relationship between the woman and the perpetrator before the assault.

- A description of psychological interventions employed at CVS was made based on an interpretative analysis of psychological records of six therapies.

Results: Eighty-eight percent were diagnosed as suffering from ASD. Fifty percent were diagnosed as suffering from medium to severe PTSD. Younger victims and victims who had not had an intake of alcohol/and or drugs before the assault exhibited the most severe symptoms. Eighty-two percent reported further 
strains than the assault in the aftermath. The most strainful areas were found connected to work/studies, police reporting, and network support.

Conclusion: The results elucidate how rape and attempted rape may be seriously traumatizing and how it affects several areas of the victim's life.

It is suggested 1) that victims of sexual assault may need psychological treatment in the acute aftermath, as well as on a long-term basis and 2) that the interventions employed should be flexible in order to comply with the individual victim's readiness for adaptation and integration of the trauma at physical as well as psychological and social levels of functioning. 


\section{Psychotic Symptoms in Rape Survivors: Signs of trauma, not schizophrenia}

Andrew Moskowitz, Ph.D., Clinical Department of Mental Health, University of Aberdeen, United Kingdom

Key words: psychosis, trauma, dissociation, rape

Symptoms traditionally considered characteristic of schizophrenia may occur during rape experiences or develop afterward. It is important that they be recognised as trauma-related and not (generally) suggestive of a psychotic disorder. Three symptoms are discussed in this presentation: catatonia, delusions and auditory hallucinations.

Catatonia, originally associated with schizophrenia, is now considered to occur more often in association with affective disorders or serious medical conditions. While it has been considered a form of movement disorder, I have argued that catatonia is best considered an evolutionary-based fear response, in situations in which fighting or fleeing was not successful or is not possible. It is particularly associated with the co-occurrence of extreme fear and physical restraint, and has been reported in car and plane crashes as well as in rape. Rape survivors who experience catatonia (sometimes called 'rape-induced paralysis') - between 37 and $52 \%$ - feel that they are frozen and cannot move or call out, despite being hyper-alert. They often experience considerable guilt about this reaction, not understanding why they weren't (or stopped) fighting or calling out, not realising that catatonia is a hard-wired response that has evolved through life-threatening encounters with predators.

Secondly, it is becoming increasingly recognised that psychotic symptoms delusions and hallucinations - are not uncommonly associated with posttraumatic stress disorder, including that which occurs after rape. Several studies have found that almost $50 \%$ of persons with rigorously diagnosed PTSD can experience delusions or hallucinations, some of which may include themes that are not clearly related to the trauma. This has led some to propose a 'psychotic' subtype of PTSD.

Finally, auditory hallucinations (voices), of all psychotic symptoms, has been most clearly linked to traumatic experiences, particularly sexual abuse. Because of this, I have proposed that voices be considered a dissociative, not a psychotic, symptom. Voices can develop in persons who were raped, even without preexisting childhood abuse, may take on the characteristics of the perpetrator, and tend to be highly self-critical or abusive in nature. 
The clinical implications of the above are that the peri- and post-traumatic symptoms of rape survivors which appear to be psychotic, such as catatonic reactions, delusions and hallucinations, should not routinely be interpreted as indicative of a psychotic disorder such as schizophrenia. Rape survivors who experience such symptoms should be reassured that they are not 'going crazy' (unless there is other evidence, beyond the mere presence of these symptoms, for the development of a schizophrenic disorder). 


\section{Prisoner Rape: Using Narrative Therapy to Address Sexual Assault in Men's Prisons}

Andrew Robert Duggan, Senior Lecturer, School of Health and Human Sciences, University of Huddersfield, England.

Key Words: Prison, Male, Rape, Narratives, Re-storying

Introduction: No-one really knows just how many people are raped within prisons worldwide because those who are assaulted rarely report the assault for fear of the response. However, it is estimated that at least $80 \%$ of the Male prison population in the UK have suffered some form of sexual abuse, either as children or adults, and many men have been subjected to rape and/or sexual abuse within the prison system. In many cases when a prisoner makes an allegation of sexual abuse/rape, they are often removed from the prison, leaving the abuser to remain, and leaving the 'victim' feeling even more traumatised by his experience.

With the staggering growth of the prison population over the past two decades, such ignorance and a lack of response by the authorities is more unjustifiable than ever.

In my clinical work and conversations with men in prison I have come to learn about some of the effects of rape. Whilst rape affects men in similar ways to women i.e. anxiety, anger, sadness, self-harm, men react in different ways after being sexually assaulted. This often results in increasing outbursts of hostility and aggression. Over time, they may also question their personal sexual identity, or may downplay the effects of the assault.

In this workshop the principles and practice of narrative therapy will be explored in relation to addressing the effects of rape in Men's prisons.

Narrative therapy is sometimes known as involving 're-authoring' or 're-storying' conversations. As these descriptions suggest, stories are central to an understanding of narrative ways of working. Through the stories of the men who have been raped, it is hoped that alternative stories will develop, stories of survival, stories of resilience and resistance and the discovery of authentic self.

Objective/Purpose: To raise awareness about the issue of rape in prisons; reach out and give a voice to prison rape survivors; support those workers both inside and outside prisons who are trying to deal with the issue of sexual violence in detention; and bring about appropriate law reform and changes to prison administration in order to prevent prisoner rape. 


\section{Cognitive Behaviour Group Treatment for Adolescent Girls after a Single Rape (STEPS)}

Iva Bicanic, University Medical Center, Psychotrauma Center for Children and Youth, Utrecht, The Netherlands

Key words: rape, adolescents, PTSD, cognitive behaviour therapy, group therapy

Introduction: Rape is a gender-specific crime that disproportionally affects young women. Especially adolescent girls are at heightened risk for rape, since they are engaged in exploring the fine boundaries of intimacy and sexuality, as part of normal adolescence. Rape can have a devastating effect on the social, cognitive and sexual development of adolescent girls. Most raped girls feel reluctant to disclose due to fear, shame and guilt and suffer from posttraumatic stress disorder (PTSD) in silence. In the Dutch Psychotrauma Center for Children and Youth a cognitive behavioural group treatment (STEPS) has been developed for raped adolescent girls and their parents, aiming at reducing PTSD and normalizing daily life. The unique character of the program is that its participants have been raped once and have not experienced prior sexual trauma.

Objective: The objective of the presentation is to describe the development and initial evaluation $(\mathrm{N}=40)$ of a cognitive behaviour group therapy protocol for adolescent girls, who suffer psychologically from the consequences of a single rape.

Method: The intervention is a cognitive behaviour treatment, based on PTSD models from Foa and from Ehlers \& Clark. The STEPS group treatment includes psycho education, exposure to the traumatic memories by writing and speaking about it, exposure in vivo, cognitive restructuring and relapse prevention. The parallel support group for the parents aims at sharing rape-related feelings and thoughts and guiding parents in how to successfully support their child in processing sexual trauma. The STEPS program consists of 8 weekly sessions for the girls and 6 weekly sessions for the parents.

The STEPS protocol consists of a manual for therapists, a working book for every girl and a working book for every parent (couple). STEPS has been published in 2007 and recorded on DVD (subtitled in English).

Girls and their parents are assessed before and after treatment with standardized self-report questionnaires until one-year-follow up.

Results and conclusion: 40 raped girls treated with STEPS showed highly significant improvement in symptoms of Post Traumatic Stress Disorder, depression and anxiety. None of the raped girls had experienced prior sexual trauma during childhood or adolescence. Treatment gains were also maintained at 
follow-up. STEPS was highly acceptable, with an overall drop-out of $2 \%(n=1)$. Despite its limitations, the findings of the study are encouraging and can be applied to benefit mental health care professionals in the challenging area of rape. 


\section{Sexual Torture of Women as a Weapon of War: The Case of Bosnia-Herzegovina}

Libby Tata Arcel, University of Copenhagen

Women and men have been tortured sexually by all sides in the wars in Croatia and Bosnia-Herzegovina. All documentation proves that systematic rape was committed by militia, military personnel and other persons in authority as a weapon in ethnic cleansing.

On the basis of 55 stories an analysis is presented of specific patterns and characteristics of the war rapes. The analysis discusses critically some feminist conceptualizations of war rape and alternative explanations are put forward.

The rapes in Bosnia-Herzegovina have led to a change in the conceptualisation of war-rape, especially in its legal aspects, that cannot be overvalued with respect to the protection of the survivor. From being understood previously as a "by-product of war" which often put the blame on victims, war rape is now defined in legal terms as a politically motivated act namely as sexual torture. The psychological and health consequences of sexual torture are discussed.

The analysis discusses finally the reasonableness of defining war rape as physical torture and discusses some of the reasons that contributed to "the conspiracy of silence" with respect to gender-specific violence during war. 


\section{A Register Study of Post-Rape Health Care Use}

Ask Elklit, University of Aarhus \& Mark Shevlin, University of Ulster

How do we achieve reliable knowledge about pre-existing and post-trauma vulnerability in rape victims? Prospective studies and control groups are essential as is objective information. These methodological demands are difficult to comply with due to a number of reasons. The comprehensive Danish registration system offers the possibility of making quasi-prospective, matched-control studies. Setting, design, and participants

This study was based on the Danish Civil Registration System (CRS). All female rape survivors $(\mathrm{N}=103)$ visiting the Centre for Rape Victims $(\mathrm{CRV})$ at the University Hospital in Aarhus, Denmark during 2003 were identified and demographic information was added based on the individual civil registry number (CPR). The CPR data were used to extract a control group of 10 women for each rape victim with the same age and living in the same municipality at the year of the rape. Any women who had visited the CRV since 1999 were not included in the control group. The annual number of visits to the general practicioner (GP) from 1999 to 2006 was used to study the impact of the rape.

Results: Similar to previous research, we found a significant post-rape increase in health care use measured by annual number of GP visits. In contrast to earlier studies, the increase reached a peak during the year of the rape, and the slope for the following year suggests that this increase might continue to ascend. The study also indicates a higher baseline level of GP visits in rape survivors that could be interpreted as a token of higher physical and/or psychosocial vulnerability.

Implications: The study converges with existing research and gives reasons for future research to follow the health care use of rape survivors for longer time periods as their somatic state might continue to result in a heightened number of GP visits and other medical services. The increased medical costs and the human suffering might justify more intensive early interventions for rape survivors. 


\section{Legal and Health Consequences of Sexual Violence in Aarhus}

Ole Ingemann-Hansen ${ }^{1}$, Ole Brink ${ }^{3}$, Svend Sabroe ${ }^{4}$, Villy Sørensen ${ }^{5}$, Ask Elklit ${ }^{6}$, Annie Vesterby ${ }^{2} .{ }^{1}$ Sexual Assault Centre, Aarhus Univ. Hospital, Aarhus, Denmark; ${ }^{2}$ Inst. of Forensic Medicine, Univ. of Aarhus, Aarhus, Denmark; ${ }^{3}$ Dept. of Orthopaedics, Aarhus Univ. Hospital, Aarhus, Denmark; ${ }^{4}$ Inst. of Public Health, Univ. of Aarhus, Aarhus, Denmark; ${ }^{5}$ Police District of Eastern Jutland; ${ }^{6}$ Dept. of Psychology, Univ. of Aarhus, Aarhus, Denmark

Key words: clinical forensic medicine, legal outcome, PTSD, pelvic pain

Introduction: From a clinical forensic medicine point of view the evidence collected could have impact on the legal outcome of the rape case. Also victim and assault characteristics could have influence as well as to predict posttraumatic stress disorder (PTSD) and pain symptoms postassault. Conviction rates of defendants vary from $10 \%$ to $69 \%$. Significant associations between successful prosecution and evidence of trauma, uses of weapons and severe coercion have been found, but inconsistently. PTSD and pelvic pain is a rather common consequence of sexual violence. Specific and immediate predictors alerting e.g. crisis centre employees seem imperative in order to prevent or reduce the health sequelae.

Objective: To ascertain the legal and law enforcement aspects of cases of sexual assault and determine associations between conviction and victim characteristics, assault characteristics, and medical findings. In addition, the prevalence and the victim- and assault-related predictors of PTSD, pelvic pain, and back pain, would be determined.

Method: Cases in a well-defined geographical area were identified in a five-year period from November 1, 1999 to December 31, 2004 in the files of three data sources: the police departments, the sexual assault centre, and the Institute of Forensic Medicine. In total, 307 cases were reported to the police departments, and the legal outcome was known in 277 . For a survey 333 victims were eligible and had the questionnaire mailed 2, 3, 4, or 5 years postassault. Response rate was $28 \%$. The Harvard Trauma Questionnaire and a 4-item checklist developed for self-report assessment of pelvic and back pain was used.

Results and conclusion: Determinant for conviction was use of severe coercion by the perpetrator (OR 7.1). No forensic findings were associated with conviction. The police authorities filed charges in $55 \%$ of the cases, and $19 \%$ of all cases ended with conviction. In $19 \%$ of cases, the forensic clinician did not find sperm detected later by the genetics laboratory. Forty-five percent fulfilled the diagnostic criteria for PTSD, and $24 \%$ had a subclinical condition. Thirty-three percent and 
$38 \%$ had experienced pelvic or back pain. Completed intercourse was a predictor for PTSD development.

A study is necessary that examines the primary outcome of the evidence collection and documentation used by the police. The findings of treatmentdemanding PTSD among $69 \%$ of the victims, and the long duration - also of pelvic pain and back pain - are alarming. Future emphasise should be put on how to reach the referred victims for follow-up. 
Poster Presentations 


\section{Was it Rape? A Study of Human Rights and Rape Cases in Denmark}

Camilla Laudrup, MA Political Science, researcher at Centre for Victims of Sexual Assault, National Hospital of Denmark, 2004 \& Helle Rahbæk, MA Political Science, senior consultant and researcher, ALS Research ApS, Copenhagen, Denmark

Key words: Human rights, access to justice, prosecution, gender, ethnicity

Objective: With human rights as the reference, the objective of the study is to gain more knowledge on the background for the fact that only few reports of rape in Denmark are brought before a court of law. The vast majority of reported cases are closed - discontinued - because the public prosecution finds that a conviction of the accused is unlikely due to 'the state of the evidence'.

Method: The objective of the study is to analyse the police and justice system's own story telling regarding rape cases in Denmark. Through an analysis of discourses prevalent in the justice system's encounter with sexual assault cases discourses of rights, gender and ethnicity - the study discusses some of the barriers that prevent rape cases from being brought to trial and it explores ways of breaking down such barriers in order to improve access to justice for victims of rape.

The study's data consists of all police records of rape reported in 2004 in four police districts, and an interview survey with a number of prosecutors, criminal investigation departments, court appointed lawyers, legal counsellors of rape victims, medical psychological professionals working with rape victims, and human rights experts.

Conclusions: Rape cases fundamentally challenge the judicial system's logic and practice of implementing rules of objectivity and rationality. The assessment of 'credibility' of both the victim and the alleged perpetrator plays a critical role in determining the fate of reported rape cases and introduces an unfortunate element of arbitrariness as to on what grounds cases are discontinued. Norms and values of police investigators and public prosecutors influence the outcome and most likely correspond to the societal majority's views on proper sexual relations and behaviour, leaving more or less deviant variants - whether based on sexuality, gender or ethnicity - in a minority position. In this light, acquiantance and partner rape cases are often experienced as 'difficult' or even 'impossible' cases to prosecute, whereas assault rapes are characterised as 'real' and 'easy' rape cases. Victims of rape committed by an acquiantance - in practice - are less likely to obtain legal redress than women subjected to sexual assault committed by a stranger. 
The study recommends an acknowledgement of rape cases challenging the judicial system, and the need to move assessments of 'credibility' into the courtroom to the largest extent possible in order to secure transparency and access to justice for both the victim and the accused.

The study is presented thoroughly in Laudrup \& Rahbæk (2004) Var det voldtægt? En undersøgelse af menneskerettigheder og voldtægtssager i Danmark. Center for Voldtægtsofre, Rigshospitalet, 2004

http://www.rigshospitalet.dk/topmenu/Nyheder+og+presse/Nyheder/Nyhedsarkiv Var+det+voldtaegt.htm 


\section{Case Closed - Rape and Human Rights in the Nordic countries}

Amnesty International, Danish section; Amnesty International, Swedish section;

Amnesty International, Finnish section; Amnesty International, Norwegian section

Introduction: Nordic women who have been subjected to sexual violence will find that there is only a slim chance that reporting the assault to the police will result in criminal proceedings and the perpetrator's conviction. Very few reports of rape lead to a formal prosecution. The great majority of cases are closed discontinued - by the police or public prosecutor before they reach the courts.

Objective: The report examines the attrition process of rape crimes and discusses some of the obstacles that prevent rape cases from coming to trial. It explores ways these obstacles can be removed in order to improve the handling of rape cases and the access to rights for rape victims in Denmark, Sweden, Norway and Finland.

Method: The report is mainly based on existing research and available information about rape crimes, which has been compiled to give a comprehensive picture of the attrition process, and analysed in a human rights framework. As an Amnesty International report it includes recommendations to the Nordic governments.

Conclusion: The report concludes that the Nordic countries do not meet their human rights obligations to respect and protect women's right to sexual self determination and equal access to legal protection. Rape is one of the most serious attacks on the sexual integrity and autonomy of a person. Every year many thousands of women are raped in the Nordic countries. Studies indicate that for various reasons, the vast majority of the victims will never report the crimes to the police. Still, thousands of women do report the crimes they have been subjected to, but their claims for justice and reparation are rarely met; only between 12 and 25 per cent of the reported rapes go to court in the Nordic countries.

The report points to different reasons for the lack of protection for rape victims in the Nordic countries:

- inadequate legal framework

- flaws in the police investigation

- flaws in prosecution practices

- gender based and stereotyped attitudes towards victims of rape

- lack of transparency in the legal process

- lack of access to proper support services for victims

Rape is a form of gender-based violence against women, and victims' lack of protection and reparation may effectively constitute gender discrimination. 


\section{Legal Issues on Rehabilitation of Rape Survivors}

Varun Chablani ${ }^{10}$, Chandan Kumar Gantayat ${ }^{11}$, Gujarat National Law University, Gandhinagar, Gujarat, India.

Key Words: South Asia, Civil War, Religious laws, Social stigma

Introduction: Rape is an offence to the body of a person (usually a female) by another person (usually a male) when he has sexual intercourse without the consent of the victim. The motives may be ranging from revenge, anger, sadism or just sexual gratification. It is one of the oldest crimes in humanity. In many countries, it is a violent sex crime. It may be classified as a crime against humanity and a war crime there are various issues relating to such a sensitive multi dimensional topic.

Objective: This Paper seeks to understand the socio legal issues relating to the justice and rehabilitation for the survivors of rape with special reference to South Asia. It explains the plight of rape survivors. Firstly, the stigma attached by the near and dear especially in the conservative societies of South Asia. This would be substantiated with extracts from popular media, like Bollywood. Secondly, the problems in filing the FIR, the embarrassment that the survivor has to undergo, just for a simple report to the police. Thirdly, the impact of local and religious laws, and the interpretation of such laws by the local authorities like the gram panchayat. Fourthly, the apathy of the judiciary, and the rehabilitation of the rape survivors after the punishment of judgment is given. This paper also focuses on the legislations on these issues, and its lacunas. Also, it mentions about the impact of the NGOs in helping in the rehabilitation of the rape survivors. Finally, the authors explain the situation of rape survivors in the civil war in South Asia with special reference to Afghanistan and Sri Lanka.

Procedure: The method of this research would be through the sources of various NGOs in the city of Ahmedabad, India. Doctrinal research would also be included. The various legislations in India will also be critically analyzed.

Conclusion: The paper concludes with recommendations and suggestions, in trying to cover up the lacunas of the legislations in India. It also gives suggestions on how to change the societal view in treating the survivors of rape. It also suggests on the method of giving survivors of rape better dignity in the society.

10 B.Com LL.B (II Year)

${ }^{11}$ B.A. LL.B (II Year) 


\section{The Role of the Judicialry and Community Based in the Fight Against Rape}

Mr.Mudoh Frankline,Mrs Ayomo Clementina,Mr.Mukom Divine. PRISON

FELLOWSHIP - Cameroon, Research Department, Yaounde, Cameroon.

Key words: Raping is killing

Although it is often said that insecurity, social excesses like drunkeness and even drugs in certain social settings expose a lot of people to rape, we recently realised poverty, frustration and the absence of control and love as a result of separation from dear ones can easily expose others in the arms of rape. When people go to jail, we expect that they go through a kind of reformation so as to come out and mind their ways and fit better in society they left behind. Legislation is therefore expected to cover the responsibility they leave behind either entirely or partially, depending on the various circumstances. But from a survey carried out by the members of the research department of the Prison Fellowship - Cameroon, it was realised that families left behind by these prisoners end up not being able to meet up with basic needs and as a result get frustrated are exposed to a lot of neglect and many other forms of dangers.

Amongst other projects in our organisation, we take care of the weak and vulnerable family members of prisoners. We noticed that when women engage in excessive drinking, they easily fall prey to orchestrators of rape. In a drunken state, they may not even be able to identify the culprits and so will not be able to make a good case. In most of these cases, it is the women and the girl children that are mostly affected. From interviews and experiences, we noticed that there are no subventions or even organisations or institutions geared at taking care of the needs of these persons. With the lack of such assistance therefore, the females take over the roles of bread winners. Children drop out of school to assist and so, some girls find themselves in millieus whereby they become sheep to the male tigers of our cruel society.

After a critical examination of the situation in the northern parts of Cameroon, we realised that the custom around there does not really permit women to go to school or attend church service with the men. In the absence of the father who also plays the protective role in the family, other men openly force their children or wives to bed. If at all legislation could be fashioned as to cater and protect such vulnerable persons and above all check certain addictive habits and other excesses, then the rate of such ills will well be reduced. Should there spring groups or institutions that care about the welfare of people in such situations, then we will well realise the disappearance of such practices. 


\section{Support Strategies for Women Affected by War-related Sexualised Violence}

Karin Griese, medica mondiale, department of trauma work, Cologne, Germany

Medica mondiale is an international non-governmental organization who supports women and girls who have been sexually violated during war and civil conflict. It also provides services for women affected by other forms of gender-based violence in post-war and conflict zones. medica mondiale built and supports women's psychosocial and counselling and training centres in Bosnia and Herzegovina, Albania, Kosovo, Afghanistan, Liberia and DRCongo and supports small scale psychosocial projects for women affected by violence in Cambodia, East Timor, Iraq, Israel, Nepal, Mexico, Siera Leone, South Afrika, Turkey and Uganda. The NGO uses a holistic, multidisciplinary and women-centered approach. Direct services, training of professionals and political lobby and advocacy work for women's rights are characteristics of medica mondiale's strategies.

The poster will:

1. Describe the phaenomenen of rape as a weapon of war - it's extent, character and logic, illustrated amongst others by a world map.

2. Summarize the consequences of war-related sexualised violence during war for women and girls on a psychosocial, medical and legal level based on assessments in DRCongo, Liberia and Kosova.

3. Present the overall work approach of medica mondiale - illustrated by graphs and pictures.

4. Discuss lessons learnt of 15 years work experience of medica mondiale with survivors of war-related sexualised violence. 


\section{Expanding Punishment: The Need for a Coordinated Legal and Public Health Response for Victims of Systematic Rape in Post- Conflict Settings}

Alexandra R. Harrington, Doctor of Civil Law candidate, McGill University, Montreal, Canada

Key words: Systematic Rape, Conflict, International Law

The issue of how to prosecute those responsible for instigating systematic rape is frequently discussed by legal scholars and the international legal and diplomatic community. The issue of providing health and rehabilitation services to the victims of systematic rape - as well as their families and communities - has been taken up by various NGOs and is often considered a public health concern. While this dichotomy seems to reflect the competence of each profession, it creates a vacuum in terms of providing victims of systematic rape remedies and rights at law which tie into access to health care, shelter, protection, and state support. It also entrenches the mindset that law and public health should only address certain aspects of rape and its aftermath. The goal of the proposed presentation is to discuss this vacuum and the results of it on state and society so that legal and public health constituencies can understand the need to work together to address their individual and shared roles in filling the vacuum.

The presentation will start with a discussion of recent conflicts in which systematic rape has been used as a weapon of war. The impact of systematic rape on its victims will then be discussed at a general level before turning to several case studies. The goal of these studies is to illustrate the many law and health related problems faced by victims of systematic rape and the legal void that faces them when they seek to address these problems. For instance, many states in which systematic rape has been used recognize children as citizens only through their fathers. When the father is unknown, both the mother and the child suffer the consequences and have no legal remedy available to them. Additionally, many victims of systematic rape are shunned by their families and/or their communities; while these victims may seek assistance from private NGOs, there is no protection of their lives or ability to survive at law in most situations. Such problems inhibit victims of systematic rape from recovering from their own traumas and resuming their place in a functioning state; they also inhibit recovery and forward progress by the state overall.

The presentation will suggest that the international legal community, the domestic legal communities in affected states, and the public health community need to work together to address these issues by enshrining victims' assistance and rights in law and in practice. 


\section{Prosecuting Rapists in Wars: Bosnia and Rwanda Cases}

Igbinosa, Samson, Obadamrshan, Emma. Halom Nigeria Company Limited., Benin City, Nigeria

"Rape remains the least condemned war crime; throughout history, the rape of hundred of thousands of women and children in all regions of the world had been a bitter reality."

Throughout history, warfare has often been accompanied by sexual assault on the female population of countries. In response, there have existed numerous legal, military, governmental, and civilian attempts to define humanitarian law with respect to the criminal treatment of these acts. These attempts, however, have failed miserably for thousands of women in times of armed conflict.

In this paper, I address the issue of rape in wartime and the attempts to bring the responsible to justice. More specifically, I seek answers to three questions. First, how has the norm against the use of rape in war evolved? I show that such a norm has long been established not only in domestic laws but also international laws and customs. Its evolution can be traced as far back as 500 BC.

I next attempt to show how, once established, such a norm matters. My second question is what, and how much, evidence is required for a violation of the norm to be acknowledged and what is the actual significance of this evidence? The international community does agree that there is rape in war; indeed, on June 27, 1996, the United Nations Court defined rape as a war crime. The use of rape has always existed in war. Still because it occurs in wartime, evidence is hard to gather and prove. It often takes months for victims to come forward because of fear and/or prolonged captivity. To answer my second question, I examine the some of the conclusions being reached by the Tribunals of Rwanda and Bosnia and the precedents set. Also, I look into the history of actual incidents of rape in Rwanda and Bosnia. These two case studies show a modern example of the common use of wartime rape and the evolution of the crime into the even more horrendous act like enforced pregnancy.

I then briefly address some of the political implications that surround this issue. My third question is as follows: what strategies bring wartime rape to the forefront of policy debates in the international community in general, and the United States in particular? This is the hardest question to answer because it entails many possibilities. I discuss what conclusions can be drawn from the documentary history of customs and traditions against wartime rape and from the two case studies. Also, I bring all this into the context of modern policy debates on humanitarian intervention. 


\section{Rape in Genocide}

Birgitte Schmidt Astrup, MD. Institute of Forensic Medicine, University of Southern Denmark

Keywords: Genocide, Rape, Sexual Assault

Introduction: Rape as a weapon of war is as old as war itself. The many wars of Europe in the 19'th and 20'th century led to formulations of the 'Geneva Conventions', hereby setting the standards of international law on humanitarian concerns during warfare. Rape is included in the fourth Geneva Convention of 1949 , but not independently prosecuted by international war tribunals before 1997 were the International Criminal Tribunal for the former Yugoslavia prosecuted rape as a 'crime against humanity'. The Rwanda Tribunal prosecuted rape as a form of genocide in 1998 .

Methods: This paper investigates the well-documented incidences of genocidal rape from the 20th century with regard to time in history, degree of systematization, purpose(s), sub-types, implementation, reaction by the international community and possible prosecution by a war tribunal.

Results: Three levels of genocidal rape are seen. 1: The individual soldier. In wars with genocidal elements, alienation of the enemy, including women and children, is a prerequisite for committing atrocities and in this environment rape is prevalent. 2: The generals: Systematic rape of civilians in enemy communities is a very effective tool of demoralization, and is often ordered by officers. 3: The political leadership behind the war: Genocidal rape and forced pregnancies is also a highly effective tool of 'ethnic cleansing', and is implemented as a separate, articulated policy of war. As said by an Arab militia warrior in the Sudan: 'We want to make a light baby'.

Conclusion: Rape is a widely used and highly efficient weapon in genocidal warfare and ethnic cleansing. Used wisely, rape can destroy the infrastructure of entire communities, and leaving little physical evidence it can be difficult to prove for a tribunal. Rape was not used in two genocides of the 20th century and one can argue that the Nazi and Kampuchean killing machines was so effective that it rendered rape as a weapon of terror superfluous. The use of rape as a weapon is carried out to perfection in the on-going conflict of Darfur. The death-toll is not sky-high forcing the international community into action, but due to this stealth weapon 2-3 million people's lives are shattered probably to the point of no return. 


\title{
The Subdued Silence: the Case of Former Jugun Ianfu in Indonesia
}

\author{
Purwaningrum, Farah, Expert Staff, Indonesian Court Monitoring (NGO), \\ Yogyakarta, Indonesia
}

Key words: former jugun ianfu, gender analysis, colonialism, comfort women.

A pessimistic version of the estimation would show that there are 400 former comfort women in Indonesia (Kompas, 4 October 2004). The comfort women or jugun ianfu were an inseparable part of the Japanese colonialism in Indonesia. The responses launched by the Government of Indonesia ignored the consequences of the sexual slavery practice. The 'gender blindness' continues when the Indonesian jugun ianfu stood and voiced their past experiences in The Women's International War Crimes Tribunal in effort to seek justice. Let alone providing encouragement for them in seeking redress from the Japanese Government, the Government of Indonesia expressed its disagreement by recalling the Indonesian Jugun ianfu had dishonour the nation by opening up a shameful matter in the Women's international War Crimes Tribunal on Japan's Sexual Slavery.

The former jugun ianfu women have to deal with other forms of repression, not only from the state but also from the society. This essay will attempt to evaluate on how the Government of Indonesia manage and provide redress for the former jugun ianfu in Indonesia. It argues the government of Indonesia's policy and responses have been counter-productive. They have caused multiplications of burden for the former jugun ianfu women. Lack of participation and aspiration of the jugun ianfu victims have marginalized them from the very process of receiving financial support as a form of compensation. In addition to that the jugun ianfu faces other multiple layers of exclusion i.e., social labelling as prostitute, economic hardship, silence, hardening their re-integration process with the local community.

This article will utilize the feminist analysis in approaching the issue and in unfolding the background of why the former jugun ianfu women are outside the blanket of protection provided by international law. A formal recognition and favourable policies would pave the way for them to seek justice. The past and present responses and policies of the Government of Indonesia have a reversed and averse result; leaving the former jugun ianfu women to be tagged as prostitutes and depriving their right of rehabilitation, compensation and redress. The gendered characteristics of international law and the failure of state-to-state track diplomacy precipitated the silence. This article concludes by postulating that the subdued silence is preserved by the hierarchy, patriarchal values in times of war, the multiplications of burdens and threats of revictimisation of the former comfort women in Indonesia. 


\section{ASD and PTSD in Rape Victims}

\section{Dorte Christiansen \& Ask Elklit}

Since the inclusion in the DSM-IV, acute stress disorder (ASD) has been heavily criticized for its lack of precision in identifying the victims most at risk for developing PTSD after various traumatic events. This study examined the predictive power of ASD on PTSD in a sample of 155 primarily female rape victims who visited a Danish Centre for Rape Victims (CRV). ASD was assessed within the first two weeks after the victims first coming into contact with the CRV by using the Acute Stress Disorder Scale (ASDS) and PTSD was assessed three months later using the Harvard Trauma Questionnaire (HTQ). Unlike most other studies examining ASD and PTSD, we used all the diagnostic criteria for both disorders by further asking about peritraumatic fear of dying, perceived life threat, and experienced helplessness as well as posttraumatic functional problems, experienced as problems in doing a job or other daily chores or sexual problems.

Using these criteria, we found an ASD prevalence of $59 \%$ and a $39 \%$ PTSD prevalence. By using a full ASD diagnosis, $64 \%$ of the victims could be correctly classified according to PTSD status. Classification was improved by removing the $A 2$ and $F$ criteria, basing an ASD diagnosis solely on the reporting of dissociative, reexperiencing, avoidance, and arousal symptoms. All four ASD symptom clusters combined correctly classified $70 \%$ of the cases. Sensitivity, specificity, positive, and negative predictive power were similar, all in the ranges between .68 and .71, indicating that about $70 \%$ of the victims who initially met criteria for the four ASD symptom clusters later developed PTSD, and that an equal number of victims suffering from PTSD three months later had initially reported ASD symptoms.

In conclusion, ASD may be the best tool we have at the present time for the early identification of PTSD cases but it fails to identify at least $30 \%$ of those most at risk for developing PTSD and it appears to account for only some of the PTSD cases, leaving $30 \%$ of the cases unaccounted for. Furthermore, a regression analysis based on ASD symptom severity and sexual problems could only account for $28 \%$ of the PTSD symptom variance. Though ASD may be useful in identifying probable PTSD cases and account for some of the variance in symptom severity, there is a need for research to find better ways of identifying those most at risk of developing PTSD after rape as well as other traumatic experiences. 


\title{
Predictors of Aacute Stress Symptoms in Rape Victims
}

\author{
Louise Due, Dorte Christiansen \& Ask Elklit
}

Introduction: Traumatic experiences often result in devastating disorders such as posttraumatic stress disorder (PTSD) and the newer acute stress disorder (ASD) as well as more general symptoms of distress. Though research has been lacking, some studies have suggested that even though early PTSD share some symptom overlap with general distress, the two constructs are independent.

Purpose: The purpose of the present study was to test the hypothesis that though correlated, early posttraumatic symptoms and symptoms of general distress represent distinct ways of reacting to trauma.

Method: We studied ASD and general distress as well as a number of possibly relevant variables in a sample of 153 primarily female rape victims seeking treatment and assistance at a Danish Centre for Rape Victims (CRV). ASD was assessed using the Acute Stress Disorder Scale (ASDS), a self-administered questionnaire focusing on symptoms of dissociation, reexperiencing, avoidance, and arousal. General distress was assessed via the Trauma Symptom Checklist (TSC) which was originally developed to measure the effects of childhood sexual abuse but has shown to be a valid measure of general distress after a variety of traumatic experiences.

Conclusion: Preliminary results showed that ASDS symptom score and TSC symptom score correlated highly with each other $(r=.79)$. A regression analysis showed that feelings of guilt and shame as well as functional impairment and hopelessness significantly predicted symptom variance for both general distress and ASD. General stress symptoms were further predicted by post assault fear and relational problems. In a second step, dissociation was introduced to both models, but it only reached significance in the ASD model, where it weakened the relationship between ASD symptom severity and all three previously significant variables, causing functional impairment to become insignificant. At the final step, symptoms of general distress were introduced into the ASD model, and ASD symptoms were introduced into the model predicting general distress symptoms. Both variables were highly significant predictors of the other, causing most other variables to loose significance. In the final model for ASD, only dissociation and general distress symptoms were significant, explaining $66 \%$ of the ASD symptom variance. In the other model, ASD symptoms and relational problems explained $71 \%$ of the general stress symptom variance. In conclusion, ASD symptoms and symptoms of general distress correlate highly with each other but dissociation is 
uniquely associated with ASD symptoms and relational problems are uniquely associated with general distress. Though ASD and general distress interact to increase distress and dysfunction, our results suggest that they are distinct ways of reacting in the acute aftermath of trauma. 


\section{The Adolescent Resilience Programme: Ending Inter-generational Sexual Abuse}

Nicole Robertson, BA BSW, University of Sydney. Programme Development for Waitakere Abuse and Trauma Counselling Service (WATCS).

Young women who have experienced child sexual assault exhibit a number of negative behavioural sequelae and they are at risk for further abuse. Research has indicated that there are a number of protective factors which moderate these negative effects. These factors include remaining engaged in their school life, maintaining positive peer relationships, continuing to make plans for their future and identifying at least one adult family member who supports them appear to be able to continue to develop emotionally following their experience of abuse.

These findings support the work of Martin Seligman and the positive psychology movement which has developed programmes to encourage resilience in young people by providing them with the skills required to deal with adversity.

The Adolescent Resilience Programme uses qualitative methodology and adopts a multi-systemic approach by working in partnership with the adolescent, members of her family. The intervention uses opportunities within the systems she engages in to develop protective skills and build resilience.

This workshop will provide an overview of the adolescent resilience treatment model, with a focus on intervention for families in which mothers and daughters have been sexually abused. The workshop will invite discussion on how best to serve the needs of young women and their families and develop strategies to reduce the risk of ongoing sexual abuse. 


\section{Identifying Risk Behavior and Attitudes on Sexual Coercion among Adolescents in Denmark}

Rikke Holm Bramsen, MSc. (Psychology), PhD.-fellow, University of Aarhus, Dept. of Psychology, Denmark

Due to a considerable prevalence of adolescent rapes in Denmark, the present study aims at establishing a basic knowledge of the sexual culture of Danish teenagers to help guide future preventative initiatives. The study includes a probability sample of 660 pupils (aged 14-16) from 35 schools, located in the Middle Region of Denmark. In order to identify key issues in sexual violence prevention, a range of measures on e.g. rape attitudes, risk behaviour, sexual coercion, peer influence, pornography consumption and understanding of rape are reported on. Additionally, guidelines are presented, suggesting strategies and target areas for future intervention. 


\section{Trends of Rape among Secondary Schools, South West, Nigeria}

Abiola Kayode, Olanrewaju. Assanusiyah College of Education; Ikire, Osun State, Nigeria.

Background: Rape is a crime of power disguised as sex. Men are raped, women are raped and small children are raped. This is unfortunate but true. The epidemiology of rape is a very complex issue that is difficult to find. The meaning of rape is different in countries, religions, socio-economic groups and it involves both stigma and discrimination. Therefore, rape statistics are either not available or incomplete. It is on the note that this study studied the problem, healing and hope for survivors of rape among Secondary Schools, South West, Nigeria.

Objective: To estimate the trends of sexual assault, effects and treatment of rape in Nigeria. Sexual assault is any non-consensual sexual contact, which can fondly or unwanted touching. Basically, all rape is sexual assault, but not all sexual assault is rape.

Methods: This is a review of the Nigeria police, hospitals and interview records of victims of sexual assault. These are the only official centre in this region that deals with cases of rape and sexual assault.

Results: Data was collected from the hospital file, police record; there were 11,740 sexual assault recorded over the period of six tears (2002 - 2007). During the year 2007; 709 were victims of sexual assault, 432 were victims of attempted rape, and 589 were victims of completed rape. This numbers does not include children under the age of twelve, which would increase these numbers substantially. About $72 \%$ of sexual assaults go unreported. About $44 \%$ of rape victims are under the age of twelve, only about $6 \%$ of rapes involved the use of a weapon; $80 \%$ of victims reported the use physical force. About 4 out of 10 sexual assaults take place in the victim's own house. 2 in 10 take place in outside, away from home and 1 in 12 take places in a parking garage. And these are just the cases that are reported.

Conclusion: The paper concluded that the more attention should be devoted to reduce the rate of rape in Nigeria. Also, the governmental and non-governmental organization, even individual should take actions to campaign against rape and sexual assaults in the society. 


\section{Barriers for Help Seeking after Sexual Victimization in a Danish Context}

Marianne Lyngby, Student of Psychology at Institute of Psychology, Aarhus, Denmark.

Despite the serious consequences sexual assault can have for the victims, there seems to be relatively few victims of these assaults, who seek public help. This has also been found to be the case in Denmark in spite of a public initiative to meet the victims' needs at Acute Rape Centres. This tendency for some of the victims to stay quiet about the sexual assault also has consequences for the legal system, because the victim's reporting a crime is the first step in crime prevention.

The purpose of this study was to identify barriers for seeking help after sexual victimization in Denmark. The method is a phenomenological qualitative analysis of rape victims who did not seek help by public services after sexual assault. Eleven women, who had all been exposed to at least one sexual assault without seeking public help afterwards, volunteered.

The findings were that not all of the women had a need for help after the assault. Two of the women recovered without any need for professional help. Nine women had suffered some kind of prolonged negative psychological suffering, though. Common for these nine women was the fact, that they were all assaulted as teenagers. A reason not for seeking help among a large group of these women was, that they did not at first think of the incidence as rape or sexual assault, for which they were entitled to seek help. This idea was caused by negative selfimages previous to the assault, fear of the perpetrator and scripts about sexual intercourse and rape previous to the assault. These scripts were particularly prone to lead to feelings of guilt and shame. Instead of seeking help these women coped by trying to avoid thinking of or talking about the assault. Lack of resources immediately after the assault also prevented the women form seeking public help. Furthermore most of the interviewed women had negative expectations of police and court system procedures concerning rape and sexual assault reports. Because they associated public service with police report and medical help, they did not think of public service as a place, where they could seek support and compassion, which most of the women were in need of after the assault. These findings will be used as part of an evaluation of the public effort to help victims of sexual assault in Denmark. 


\section{Rural Communities: No Rapes or No Help?}

Louse Hjort Nielsen, Cand. Psych., MSc Psychology, The Danish Research Unit of Psychotraumatology, Department of Psychology, University of Aarhus, Denmark \& Ask Elklit.

Key words: rape victims; urban; rural; Denmark

Little is known from research about barriers to seeking and receiving help following domestic violence, rape, attempted rape, and sexual assault in Denmark. This study examined possible regional differences in reporting rape and sexual assault in urban and rural communities in a large region in Denmark. It was hypothesized that there would be a lower representation of rape victims, measured by the number of calls, to a regional rape crisis center in the rural communities further away from the regional rape crisis center of Aarhus compared to the urban communities closer to the rape crisis center.

A one-way ANOVA analysis showed that there was a significant association between the number of victim calls and the distance to the rape crisis center. The closer the residence of the victim was to the rape crisis center the more victim calls were registered. The results also showed a similar association between the number of victim calls and the population size of the communities.

Implications for victims in rural communities, as well as, prevention are discussed. 


\section{Rape Survivors Assaulted more than 6 Months ago.}

Linda Knudsen, Rikke Sophie Bak, MSc (Psychology). The Sexual Assault Centre (SAC) at the Aarhus University Hospital, Aarhus, Denmark.

Key Words: Rape, recovery prognosis, PTSD, psychological support, group therapy.

The Sexual Assault Centre (SAC) in Aarhus services women who have been exposed to sexual assault within 72 hours after the assault. The experience of the SAC is that some survivors are unable to participate in psychological intervention right after the assault. Instead they experience the need and motivation later on. Research has shown that $20 \%$ of the women, who has been exposed to forced sexual intercourse, have not told anybody about the incident and have isolated them selves instead. This leaves a large part of women, without the necessary, entitled, qualified and professional help.

Sexual assault is an extremely traumatic experience and survivors often experience reactions of Posttraumatic Stress Disorder (PTSD) and anxiety, isolation, depression, and sexual problems. There is a growing consensus regarding the need for psychological intervention in these cases. Research shows concordantly that repression and avoidance as coping strategies correlate with poor psychological recovery prognosis, and that chronification of PTSD increases after 3 months and spontaneous recovery is getting increasingly unlikely 6 months after the assault.

The purpose of this ongoing study is to further investigate and describe the psychological, physical, and social long-term consequences of rape for rape survivors who have not received psychological help previously and where the incident happened for more than 6 months ago. Furthermore, The SAC wants to offer psychological support, consisting of individual or group therapy based on cognitive method to the rape survivors who take part in the study. A secondary aim of the study is to evaluate the effect of the psychological interventions. The methods include a survey questionnaire, a personal interview, and an assessment of the cognitive individual and group interventions.

The project has been running for less than a year, and it has turned out to be quite difficult to get in contact with the women in question. Till now the project includes 27 women.

One group of four has completed 10 sessions of group intervention, one group of five is in an ongoing process, four women have had a very short contact with the centre and have terminated individual intervention after one or two sessions, and ten women are in an ongoing individual process. 
The clinical impression is that the participants feel deeply affected by the rape before the psychological intervention and express considerable positive changes immediately after termination. 


\section{Contextual Psychosocial Approach in Rehabilitation Program of Vive Žene Centre}

Jasna Zečević, director of Vive Žene, Centre for therapy and rehabilitation, Tuzla, Bosnia and Herzegovina \& Ibrahimefendić Teufika, gestalt therapist, Vive Žene, Centre for therapy and rehabilitation, Tuzla, Bosnia and Herzegovina

Aim: To show importance of implementation of contextually adopted Psychosocial model based on the understanding that healing of the trauma is a multidimensional long-term process that involves a work on the "micro" level (individual and local community level) and "macro" levels in the society.

Method: Presentation of development in psychosocial work in $\mathrm{BH}$ through Vive Žene work implemented by multidisciplinary team. Besides the work that requires attention of individual team members, our work in the community takes a multidisciplinary approach to reconciliation, rebuilding of trust, reduction of ethnic barriers. The goal of all activities in the Vive Žene, is to maintain and protect the mental health of our beneficiaries, which is also a way to contribute to the reconstruction of a war torn society.

The work with a beneficiaries begins during the first conversation which is usually conducted by a social worker .After a beneficiary is admitted in the stationer or outpatient department, the multidisciplinary team decides what kind of treatment is needed, and then create an individual "recovery plan" and appoints the person responsible for a particular case. Before a "recovery plan" is made, the beneficiary's entire background is analyzed: family ties, education, place of living....all this for the purpose of adapting the plan to the beneficiary's needs.

Connected disciplines that functioning both within the team and externally (other institutions), the specific quality of work in Vive Žene is the connection between the social and cultural background of a beneficiary and the kind of treatment they gets.

Conclusion: It is very important for us to take into account the context a beneficiary comes from, because in some cases it is not possible to immediately start psychotherapeutic treatment or counselling, before the beneficiary was introduced to basic principles and the meaning of the terms psychosocial assistance and support. 


\section{Dressed for Rape: Anonymous Voluntary Counselling for Female Victims by the Danish Joan-Sisters}

Annette Erler, \& Cecilie Staur. Joan-Sisters, c/o Dannerhuset, Copenhagen, Denmark www.joan-soestrene.dk

Key words: Victim Counselling, Documentation, Knowledge Sharing, Legislation, Intervention Centre

The Joan-Sisters (dan. Joan-Søstrene), located in Copenhagen, is an open anonymous counselling organisation which helps women in person, by telephone or mail. Over 30 years of contact to victims and their families all over Denmark has given us a unique knowledge base.

Besides giving lectures and information at all kind of national fora (refer also to our 2008 annual report), the Joan-Sisters use their statistical documentation in the political work for improving the rights of rape victims, and to guide the process of creating legislation. The voluntary organisation is working towards the establishment of intervention centres to change the ways that documentation and counselling are approached.

Our open counselling office shows a tendency towards victims being referred to us by the public sector because of lack of substantial services. The statistical material reflects the significant lack of preventative activities, as well as support after a rape. 


\section{The Psychological Consequences of Rape for Friends and Relatives}

Rikke Sophie Bak, Linda Knudsen, MSc (Psychology). Sexual Assault Centre at Aarhus University Hospital

Key Words: Rape, friends and relatives, PTSD

Survivors of Rape in Denmark have the possibility to get support from one of the established Sexual Assault Centres around the country. Although it is our experience that relatives and friends of rape survivors also suffer from the experience, there was no public offer of support for this group at the beginning of the study. Moreover the research in this field is sparse and much more empirical investigation is needed.

The purpose of the study was to investigate the psychological and social consequences of rape for the friends and relatives of the rape survivor and in the light of these results to offer the relatives and friends information meetings and supportive therapy if needed.

A survey questionnaire with 107 participants showed that $24 \%$ of the relatives and friends met all the DSM-IV criteria for Posttraumatic Stress Disorder (PTSD) and $36 \%$ had PTSD on a subclinical level. Preliminary analyses indicate that experiences of being let down by people you know, providing a lot of support to the rape survivor or using emotional coping style were associated with increased risk of PTSD.

A large part of the relatives and friends had other severe individual reactions as sorrow, anger, shock, feelings of powerlessness and besides that reported interpersonal problems with the rape survivor. The study showed that $66 \%$ of the relatives and friends experienced the need of help and support, which was only fulfilled for a very few of them.

In consequence, information meetings and supportive therapy was offered to relatives and friends of the rape survivors. A large part of the relatives made use of the supportive therapy while only a very few joined the information meetings. The clinical impression is that the relatives profited well from the intervention.

All in all, results from the study show that a considerable part of the relatives and friends of the rape survivor are deeply affected by the rape and that different kinds of intervention might reduce the psychological consequences of the incident for this group of "hidden" victims. 


\section{Counselling Relatives of Rape Victims}

Sabine D. Christiansen, Cand. Psych. Juliane Marie Centret, Pårørenderådgivningen, Rigshospitalet, Copenhagen University Hospital. Key words: Counselling Relatives of Rape Victims.

Introduction: Since September 2006 we have been able to offer counselling to the relatives of rape victims at the Centre for Victims of Sexual Assault at Copenhagen University Hospital.

Purpose: How do we best counsel the relatives of rape victims? As a relative your first concern is how to help that person close to you. Many of our clients rapports that it is a time where you put your own emotions on hold. This has certain implications in relation to the kind of relationship you have to the rape victim. Parents, husbands, boyfriends, girlfriends, siblings, working colleges: they all react in some ways differently. But on other points there are similarities in the problems they face taking care of the situation surrounding a sexual assault. The poster will give an insight on this; leading up to how we best counsel each individual group of relatives of rape victims.

Method: Analysing data in the clinical journals, we are in the process of finding out the specific themes, which are important for the individual groups of relatives of rape victims. This gives us a more precise understanding of how to help the relatives help the rape victim, and how to help themselves.

Conclusion: The research is still in process. The poster presentation will give an overview of what we have found until now. 


\section{The Psychological Background of False Rape Accusations}

Louise Skriver Rasmussen, MSc (Psychology)

Key words: false rape accusations, case study, coping strategies, personality

Introduction: False rape accusation has several clinical implications; e.g. women who have been raped abstain from reporting the rape to the police in fear of not being believed, and the police use unnecessary resources.

The concept of false rape accusations is sensitive and complex, and research lacks a theoretically framework. There exists no unambiguous definition and discussions on what constitutes "false" complicates the concept. Research is sparse and seldom explained in psychological terms. Existing studies (Kanin, 1994; Theilade \& Thomsen, 1987; Maclean, 1979; Jordan, 2002) explain false rape accusations as a need for an alibi, e.g. for being out late or infidelity, the need for attention or sympathy, and revenge.

Purpose: The purpose of the case study was to explain the dynamics of false rape accusations.

Method: A case study using archival data consisting of clinical case notes from 2002 to 2005 from the Sexual Assault Centre in Aarhus, the Institute of Forensic Medicine, University of Aarhus, and from the Police District of Eastern Jutland was designed.

Results and discussion: The study consisted of 12 cases (women; mean age: 21,1 years). All the women had experienced several traumatic experiences e.g. violence, previous rape attempts, loss of a loved one, family problems and problematic circumstances growing up. The women showed other symptoms e.g. suicidal thoughts and attempts, depression, abuse of drugs and alcohol, and selfmutilating behaviour. Several had had previous but unstable contact with a psychiatrist or psychologist. In 8 of the cases the reasons for the false rape accusation concerned infidelity, revenge, need for attention and a cry for help due to other problems.

Some results are in line with previous findings, some results are new: The accumulation of traumatic events and stressors. A model drawing on knowledge about trauma, vulnerability, coping and defence mechanisms, and personality/psychopathology (histrionic personality disorder) was introduced. Traumatic experiences and personality influence each other via coping and/or defence mechanisms. Further, vulnerability affects personality and trauma and vice versa. False rape accusation can be seen as an immature attempt to cope 
with traumas, other stressors and problems due to one's vulnerability and constitution of personality.

The strengths of the study are that observer biases are avoided; data can be reexamined, and the clinical notes have been made without knowing the purpose of the present study. The weaknesses of the study concern difficulty establishing causality and generalisation.

The study is presented thoroughly in Rasmussen, L.S. (2006) Den psykologiske baggrund for falske voldtægtsanklager. Center for Voldtægtsofre, Århus 


\section{Author Index}

Amnesty International.............. 38

Arcel, Libby Tata ..................... 31

Astrup, Birgitte Schmidt ........... 44

Ayomo, Clementina ................. 40

Bak, Rikke Sophie ............. 54;58

Bicanic, Iva...........................29

Bramsen, Rikke Holm............... 50

Brink, Ole.............................. 33

Chablani, Varun ...................... 39

Christensen, Gitte................... 19

Christiansen, Dorte............ 46;47

Christiansen, Sabine D............ 59

Due, Louise ........................ 47

Duggan, Andrew R................. 28

Elklit, Ask ...........32;33;46;47;53

Erler, Annette ....................... 57

Fladby, Birgit ........................... 8

Gantayat, Chandan Kumar ....... 39

Griese, Karin......................... 41

Hansen, Preben Juel ................ 15

Harrington, Alexandra R.......... 42

Hayes, Niamh ........................ 22

Helström, Lotti ......................... 7

Hilden, Malene ....................... 10

Ibrahimefendić, Teufika............56

Igbinosa, Samson.................... 43

Jansen, Helene Almind .............. 11

Jørgensen, Peter Hjorth............ 10

Knudsen, Linda ................. 54;58

Koss, Mary P......................... 18

Larsen, Hans Jakob.................. 14

Larsen, Vicky Bredkjær ............... 3
Laudrup, Camilla...................... 36

Lyngby, Marianne.................. 52

Madsen, Iben Warring............... 11

Madsen, Lasse Lund ................ 16

Moskowitz, Andrew.................. 26

Mudoh, Frankline ................... 40

Mukom, Divine........................ 40

Möller, Anna ............................. 7

Nielsen, Louse Hjort ................ 53

Obadamrshan, Emma .............. 43

Olanrewaju, Abiola Kayode........ 51

Ormstad, Kari .......................... 2

Pettersson, Kristina ................... 7

Purwaningrum, Farah .............. 45

Rahbæk, Helle ....................... 36

Rasmussen, Louise Skriver....... 60

Ravald, Klara ............................ 7

Robertson, Nicole .................... 49

Rust, Annalise........................ 24

Sabroe, Svend ........................ 33

Schei, Berit .............................. 5

Schiønemann, Leif.................. 14

Shevlin, Mark ........................ 32

Snare, Annika ....................... 13

Staur, Cecilie.......................... 57

Sørensen, Villy......................... 33

Thomas, Mark........................ 20

Vesterby, Annie ...................... 33

Vinum, Mette Lise .................. 11

Worm, Anne-Marie .................. 10

Zečević, Jasna ........................ 56 


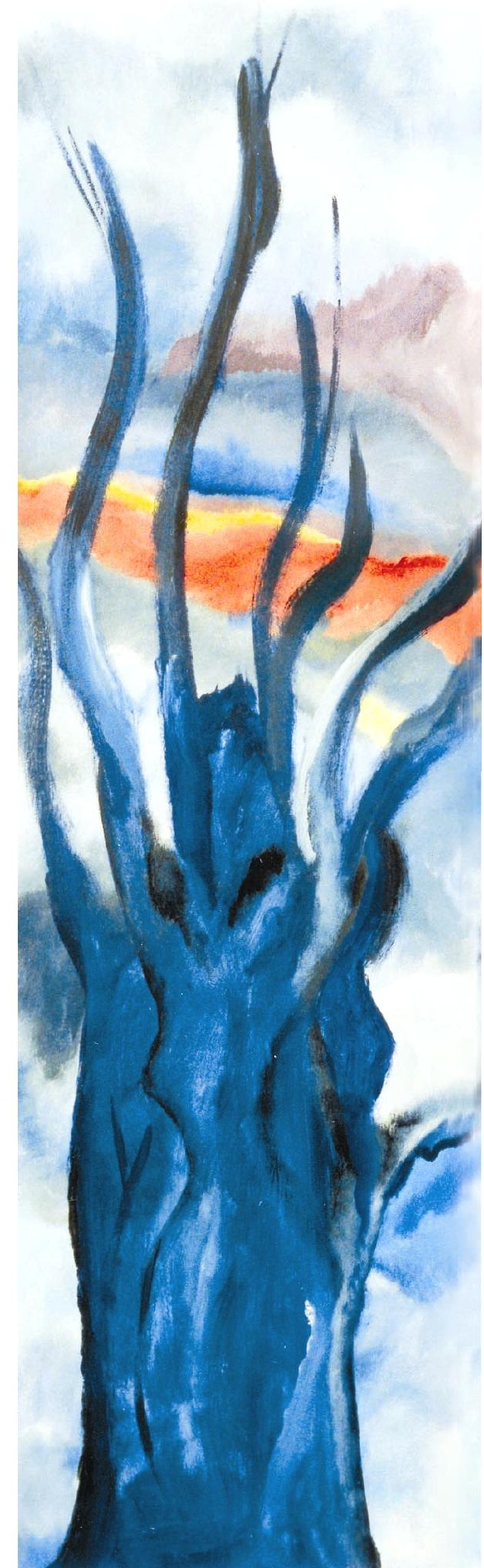

